Olivet Nazarene University Digital Commons@ Olivet

Faculty Scholarship - Library Science

Library

2012

\title{
Using join.me to Help Library Patrons
}

Ann Johnston

Olivet Nazarene University, ajohnsto@olivet.edu

Follow this and additional works at: https://digitalcommons.olivet.edu/lsci_facp

Part of the Educational Methods Commons, and the Library and Information Science Commons

\section{Recommended Citation}

Johnston, Ann. "Using join.me to Help Library Patrons." Library Hi Tech News 29.8 (2012): 5-6.

This Article is brought to you for free and open access by the Library at Digital Commons @ Olivet. It has been accepted for inclusion in Faculty Scholarship - Library Science by an authorized administrator of Digital Commons @ Olivet. For more information, please contact digitalcommons@olivet.edu. 


\section{Using join.me to Help Library Patrons}

By Ann Johnston

Informatics \& Curriculum Librarian

Benner Library, Olivet Nazarene University, Bourbonnais, Illinois

As the Informatics Librarian at Olivet Nazarene University, my staff and I are often responsible for troubleshooting our patron's technology issues. My experience with join.me began when I was told that our Campus IT would no longer be subscribing to a paid screen sharing service. One of the suggestions from the IT staff was to try join.me, a free screen sharing service. Although I was skeptical, I visited the website, https://join.me/, to test it out. It seemed to have some possibilities and appeared to be fairly intuitive.

\section{join.me}

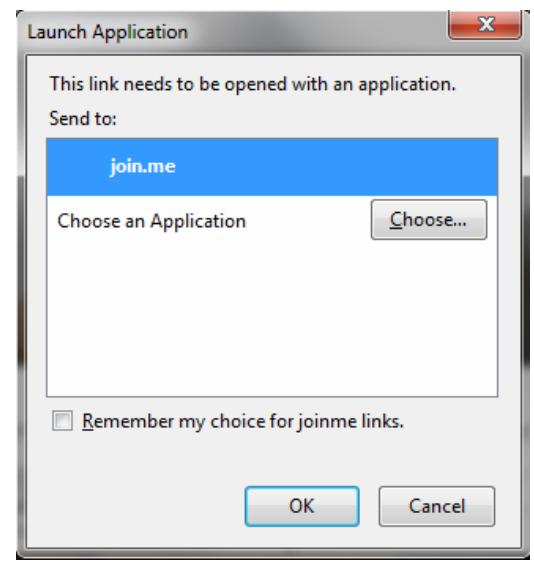

My Informatics students and I then experimented with the basic version of join.me, trying out some of the features, tempting it to fail. We were marginally impressed, but this testing was between computers on campus on the same network. What would happen if we tried with someone off-campus? I decided to recruit my thirteen-year-old niece for further testing. She had an Internet service that was only slightly better than dial up. All she had to do was allow me to observe her (from campus) while she played on her home computer. We went through the very easy steps to connect to join.me and I watched her play Farmville. It really worked! Then I asked for permission to take control of her computer. I took over the mouse and was able to navigate. After a few minutes, we switched roles and she played the game on my campus computer. I was sold.

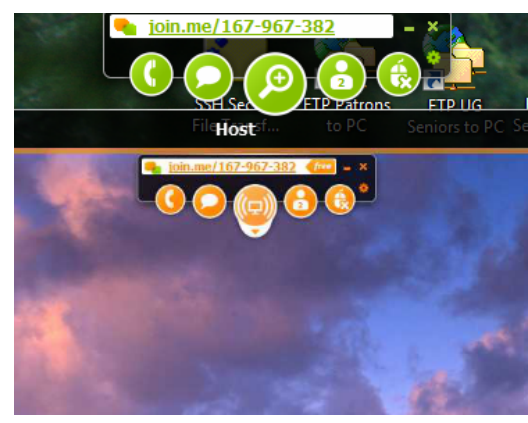


My next concern was that join.me would be too complicated to explain to the audience who needed the most help. Understandably, distance education students, who have not been back to school recently and are typically adults working fulltime jobs, often struggle with the use of technology. Many librarians have probably experienced phone calls in which communication with this type of student becomes a challenge. The patrons don't understand the terminology or even how to express their problem. Let's face it, in many cases, by the time they call for help, they are in complete frustration and want it fixed NOW!

With the needs of distance education students in mind, I put together an instruction page on our website (http://library.olivet.edu/troubleshoot/screen sharing.php) that would help guide our users through the screen sharing process. When I receive calls about login issues, I use join.me to attempt to resolve the issues. I ask patrons if they have time to screen share with me so that I can actually observe their issue. No one has ever refused. I walk them through the setup and then they show me their problem. It makes troubleshooting so much easier - as if they are in the same room. Sometimes I ask patrons for permission to control their mouse, but I try to avoid that. My goal is to make them as self-sufficient as possible. I also do not try to "fix" anything on their computers. I only collect data to help solve the problem or communicate the problem to Campus IT.

Join.me has been invaluable in helping patrons resolve their password and login issues. I have used it for a variety of other purposes, too. I use join.me with patrons to demonstrate searching strategies and help them with problems downloading pdfs. It is an effective way to identify if their problem reveals a campus-wide issue or if just a simple correction needs to be made in the user's process. I have even used join.me with other library staff members when working on a project together.

Additional comments about join.me:

1. I have used join.me from home using my phone's hotspot as the Internet provider.

2. I have used join.me to help patrons who have a dial-up service. I had to be patient because join.me does not speed up their internet service, but it is still effective. 3. Join.me is not just one browser to another browser; you can actually see and control any aspect of the patron's computer if needed.

4. Join.me works on both Apple and Windows platforms.

5. My office has recently been experimenting with the audio functionality in join.me.

We struggled with it at first and discovered it worked better once join.me was installed. For the distance education patrons, I think I will stick with the good old-fashioned landline phone for now.

6. There are apps available that we have tested on both an ipad and an android tablet. They worked great for viewing purpose. The apps do not appear to have sharing capabilities at this time.

7. We have tried having up to three viewers at one time. It worked smoothly.

Feel free to contact me with questions 
$\underline{\text { http://library.olivet.edu/email.php?id=10 }}$ 